\title{
RASIO KEUANGAN UNTUK MENGUKUR KINERJA PERUSAHAAN: STUDI KASUS PADA PERUSAHAAN SEKTOR BARANG KONSUMSI
}

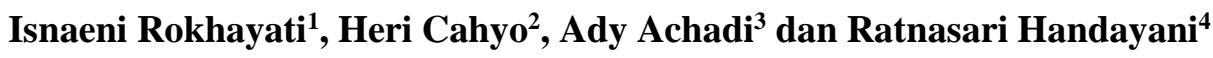 \\ 1,2,3,4 Program Studi Manajemen \\ Fakultas Ekonomika dan Bisnis \\ Univeristas Wijayakusuma Purwokerto \\ Email : isnaeni_akbar@yahoo.co.id ${ }^{1}$, herucahyouwk@yahoo.com², \\ adya.chadi1971@gmail.com ${ }^{3}$, dan ratnasarihandayani@gmail.com ${ }^{4}$
}

\begin{abstract}
ABSTRAK
Tujuan dari penelitian adalah menguji pengaruh rasio keuangan yang terdiri dari tingkat profitabilitas, likuiditas, serta leverage pada kinerja keuangan di perusahaan barang konsumsi yang terdaftar di Bursa Efek Indonesia. Data penelitian berupa laporan keuangan yang dipublish. Terdapat 16 perusahaan barang konsumsi pada 2016-2018 di BEI dan EVIEWS digunakan untuk analisis data panel. Hasil analisis menemukan net profit margin memiliki pengaruh positif signifikan pada kinerja keuangan. Dimana tingkat keuntungan perusahaan mengalami peningkata sehingga menyebabkan kinerja perusahaan akan meningkat. Current ratio dan debt equity ratio tidak berpengaruh pada kinerja perusahaan sehingga tingkat likuiditas dan leverage tidak mempengaruhi kinerja perusahaan. Kontribusi penelitian diharapkan mampu menyajikan informasi ke pihak menajemen untuk tetap memperhatikan rasio keuangan seperti tingkat likuiditas, profitabilitas dan solvabilitas. Perusahaan juga diharapkan dapat meningkatkan net profit margin, current ratio dan leverage perusahaan agar mencapai kinerja finansial perusahaan dalam keadaan baik. Hendaknya penelitian selanjutnya memperbanyak variabel lain baik variabel internal maupun variabel eksternal perusahaan, dan menambah waktu pengamatan agar dapat memberikan informasi yang lebih general.
\end{abstract}

Kata Kunci: Net Profit Margin, Current Ratio, Debt to Equity Ratio, dan Return on Equity

\begin{abstract}
The purpose of this study is to examine the influence of financial ratios consisting of profitability, liquidity, and leverage on the financial performance of consumer goods companies listed on the Indonesia Stock Exchange. Research data using the form of published company financial statements. There were 16 consumer goods companies in 2016-2018 on the IDX, and EVIEWS are used to analysis panel data. The results of the analysis found that the net profit margin has a significant positive effect on financial performance. The level of company profits has increased, causing the company's
\end{abstract}


performance to expand. The current ratio and debt equity ratio have no effect on the company's performances and that the level of liquidity and leverage does not affect the company's performance. The contribution of this research is expected to provide information to the management of the company, to pay attention to financial ratios such as the level of liquidity, profitability, and solvency. The company is also expected to increase its net profit margin, current ratio, and company leverage in order to achieve the company's financial performance in good condition. Future research should add other variables, both internal and external variables of the company, and increase the observation time in order to provide more general information.

Keywords: Net Profit Margin, Current Ratio, Debt to Equity Ratio, and Return on Equity

\section{PENDAHULUAN}

Kinerja keuangan merupakan suatu harapan tentang pencapaian dan perkembangan kondisi yang baik di masa depan pada perusahaan. Informasi tentang kondisi kinerja keuangan dibutuhkan agar bisa menilai adanya perubahan kebutuhan dari sumber daya yang dibutuhkan sehingga dapat dikendalikan serta dapat memprediksi kebutuhan kapasitas produksi perusahaan dalam jangka waktu yang akan datang (Sundjaja dan Barlian, 2003). Menurut Bastian (2006) kinerja keuangan merupakan sebuah upaya pencapaian dari semua program atau kebijakan dalam upaya untuk dapat tercapainya tujuan, visi dan misi perusahaan. Penilaian tentang kondisi kinerja finansial berhubungan dengan laporan keuangan dari sisi rasio keuangan.

Dengan analisis rasio keuangan dimungkinkan pihak manajemen terutama manajer serta yang berkepentingan terhadap keadaan kinerja finansial perusahaan dapat menilai dan mampu mengevaluasi keadaan finansial perusahaan. Ukuran rasio keuangan dapat melihat adanya hubungan dari perencanaan pencapain keuntungan serta risiko yang dihadapi untuk mengetahui efektivitas dan efisiensi kinerja operasional perusahaan. Besarnya tingkat laba yang dihasilkan dapat dihitung menggunakan rasio return on equity (ROE) sebagai tingkat keberhasilan kinerja finansial perusahaan (Husnan, 2001).

Pelaksanaan pengukuran terhadap kinerja finansial menitikberatkan di perusahaan barang konsumsi di BEI dikarenakan merupakan sektor perusahaan 
yang sangat penting bagi perekonomian khususnya di Indonesia, karena perusahaan ini menyediakan berbagai barang kebutuhan sehari-hari bagi masyarakat secara luas. Terjadi fenomena bisnis bahwa tingkat kinerja secara finansial perusahaan sektor barang konsumsi yang terus mengalami kenaikan dan penurunan pada setiap periode laporan keuangan yang menyebabkan harga saham perusahaan mengalami perubahan juga. Sehingga ini memungkinkan untuk dilakukan penelitian tentang bagaimana kinerja finansial perusahaan sektor barang konsumsi secara keseluruhan yang dapat mencerminkan tingkat kesehatan serta kinerja perusahaan.

Pengukuran kinerja finansial pada riset ini digunakan rasio net profit margin yang memperdiksikan tingkat profit yang dihasilkan perusahaan. Dalam mengukur tingkat likuiditas digunakan current ratio, sedangkan untuk melakukan pengukuran tingkat solvabilitas digunakan debt equity ratio. Pada review literatur terdahulu menunjukkan adanya ketidaksesuaian hasil penelitian seperti penelitian Nyonita et al. (2017) menemukan bahwa profitabilitas dapat memberi dampak secara parsial dan simultan ke kinerja perusahaan, sedangkan Heri (2013) memperlihatkan hasil return on equity tidak dipengaruhi secara parsial oleh net profit margin. Return on equity diperlukan untuk melakukan pengukuran tentang seberapa besar tingkat pendapatan yang akan didapatkan oleh pemilik dari modal yang sudah diinvestasikan pada perusahaan (Syamsuddin, 2007). Harahap (2015) menyampaikan bahwa return on equity dapat menunjuk atas besarnya laba bersih apabila diukur dengan modal pemilik.

Hasil penelitian dari Anggraeni (2015) menunjukkan pengujian simultan current ratio dapat mempengaruhi signifikan ke kinerja perusahaan. Likuiditas dapat menunjukkan tingkat keberhasilan membayar kewajiban utang lancar yang harus segera dibayarkan (Munawir, 2010). Pengukuran tingkat likuiditas dapat menggunakan current ratio, yang dapat menunjukkan kemampuan perusahaan ketika menyelesaikan semua kewajiban finansialnya. Penelitian Oima et al. (2015) mencatat kinerja perusahaan dipengaruhi oleh variabel likuiditas, sedangkan Nyonita et al. (2017) menyebutkan tingkat likuiditas tidak berpengaruh terhadap kinerja perusahaan. 
Variabel lain yang dapat berpengaruh pada besarnya tingkat laba perusahaan yaitu debt to equity ratio. Anggraeni (2015) telah melakukan penelitian dengan hasil uji parsial dimana kinerja perusahaan tidak dipengaruhi oleh debt to equity ratio. Selanjutnya penelitian Azzalia dan Seto (2017) menjelaskan secara parsial variabel debt equity ratio memiliki pengaruh pada return on equity. Hasil penelitian dari Purnomo (2013) rasio current ratio, net profit margin dan leverage berpengaruh pada return on equity.

Berdasarkan review literatur terdahulu terdapat adanya perbedaan hasil terhadap beberapa variabel yang dapat berpengaruh pada kinerja perusahaan, antara lain net profit margin, current ratio dan debt equity ratio pada tingkat profitabilitas perusahaan. Sehingga dalam riset ini memiliki tujuan untuk melakukan pengujian terhadap variabel internal perusahaan net profit margin, current ratio dan debt equity ratio pada tingkat profitabilitas yang dapat memperlihatkan tingkat kinerja finansial perusahaan secara keseluruhan. Hasil penelitian terdahulu yang meneliti tentang kinerja keuangan antara lain Oima et al. (2015), Purnomo (2013), Efendi dan Wibowo (2017), Nyonita et el. (2017) dan Anggraeni (2015) menjelaskan bahwa rasio keuangan memiliki pengaruh terhadap kinerja keuangan.

\section{METODE PENELITIAN}

Penelitian memerlukan laporan kondisi keuangan perusahaan yang sudah publish. Populasi merupakan perusahaan manufaktur yang terdaftar di BEI selama 2016-2018 dengan 47 perusahaan. Metode purposive sampling digunakan dalam penentuan sampel dimana jumlah sampel ada 16 perusahaan manufaktur sektor barang konsumsi yang terdaftar di BEI tahun 2016-2018. Regresi linier berganda dengan data panel digunakan untuk menganalisis data dengan bantuan EVIEWS. Pada pengujian uji Cow dan uji Hausman diperoleh fixed effect model sebagai model terbaik.Variabel kinerja keuangan yang diukur dengan rasio return on equity, sedangan variabel bebas diproksikan dengan rasio net profit margin, current ratio dan debt equity ratio. Model penelitian dapat diperlihatkan pada gambar 1. 


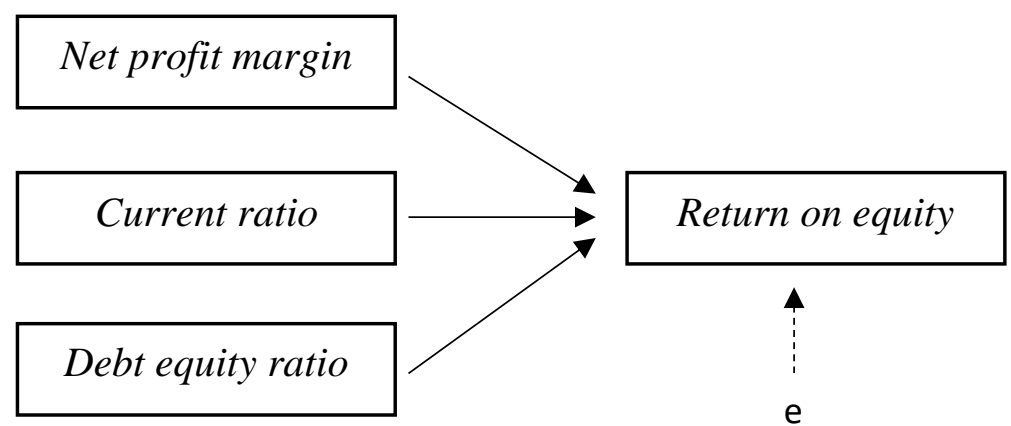

Gambar 1. Model Penelitian

\section{HASIL DAN PEMBAHASAN}

Regresi data panel menggunakan EVIEWS mendapatkan fixed effect model sebagai model terbaik dan hasilnya tersaji dalam tabel 1.

Tabel 1. Analisis Data Panel

\begin{tabular}{|c|r|r|r|r|}
\hline Variable & \multicolumn{1}{|c|}{ Coefficient } & \multicolumn{1}{c|}{ t-Statistic } & \multicolumn{1}{c|}{ t-table } & \multicolumn{1}{c|}{ Prob. } \\
\hline C & 0,347141 & 0,715608 & 1,671 & 0,477 \\
\hline NPM & 0,094677 & 4,145448 & 1,671 & 0,033 \\
\hline CR & 0,338420 & 2,182623 & 1,671 & 0,919 \\
\hline DER & 0,259221 & 2,530949 & 1,671 & 0,192 \\
\hline
\end{tabular}

Sumber : data diolah dengan Eviews

Variabel profitabilitas terdapat pengaruh signifikan ke return on equity dengan probabilitas sebesar 0,033, dimana jika tingkat keuntungan yang dihasilkan mengalami kenaikan maka tingkat pendapatan perusahaan akan naik juga. Namun, penelitian Parmono (2013) menunjukan net profit margin tidak berpengaruh signifikan pada return on equity. Tapi hasil Nyonita et al. (2017) menghasilkan yang sama yaitu return on equity dipengaruhi oleh net profit margin. Hasil penelitian dapat menjelaskan bahwa jika tingkat keuntungan dalam kinerja keuangan diperoleh perusahaan semakin meningkat maka akan berdampak positif pada nilai perusahaan. Artinya jika tingkat return on equity meningkat maka kemampuan dalam memperoleh keuntungan bersih meningkat dalam menjalankan operasinya. Tingkat profitabilitas yang semakin tinggi, memperlihatkan semakin baiknya performa perusahaan akibatnya tingkat keuntungan yang didapatkan oleh 
pemegang saham akan meningkat pula. Dengan demikian dapat menambah minat investor sehingga dapat meningkatnya permintaan saham perusahaan sehingga harga menjadi tinggi di pasar bursa.

Hasil uji analisis data menghasilkan bahwa tingkat likuiditas dengan proksi current ratio $(\mathrm{CR})$ menunjukkan bahwa tidak berpengaruh pada kinerja perusahaan, dengan nilai probabilitas sebesar 0,919. Likuiditas tidak mempengaruhi tingkat return on equity, dimana tingginya tingkat likuiditas tidak akan mempengaruhi tingkat pendapatan yang diperoleh perusahaan. Hasil penelitian ini mendukung penelitian Nyonita et al (2017), Parmono (2013), dan Oima et al (2018) dimana current ratio tidak berpengaruh signifikan terhadap return on equity. Berbeda dengan Anggraeni (2015) tingkat current ratio berpengaruh signifikan dan positif terhadap return on equity perusahaan.

Debt to equity ratio menghasilkan nilai probabilitas sebesar 0,192 , sehingga debt to equity ratio tidak memiliki pengaruh pada return on equity. Besarnya debt to equity ratio tidak berpengaruh terhadap adanya perubahan tingkat return on equity pada perusahaan. Hasil ini menunjukan bahwa tingkat leverage atau utang tidak memiliki pengaruh atas adanya tingkat keuntungan yang diperoleh perusahaan. Penjelasan Harjadi (2013) terjadinya kinerja perusahaan yang menurun diakibatkan adanya penambahan jumlah utang perusahaan sehingga perusahaan tidak dapat membayar kewajiban bunga utangnya. Sehingga kinerja perusahaan tidak dilihat dari adanya tingkat perubahan debt to equity ratio, karena tidak akan mempengaruhi tingkat perolehan keuntungan perusahaan. Hasil penelitian ini tidak mendukung hasil penelitian Efendi dan Wibowo (2017) menyebutkan secara parsial debt equity ratio berpengaruh signifikan terhadap return on equity. Namun, penelitian Anggraeni (2015), dan Parmono (2013) mendukung penelitian ini yang menyebutkan debt equity ratio tidak berpengaruh signifikan terhadap return on equity. 


\section{KESIMPULAN DAN SARAN}

Variabel net profit margin memiliki pengaruh pada return on equity, tetapi variabel likuiditas dan debt to equity ratio tidak memiliki pengaruh pada return on equity. Ternyata penentuan tingkat kinerja perusahaan tidak dapat diukur dengan kemampuan tingkat likuiditas dan tingkat leverage yang dimiliki perusahaan, tetapi hanya ditentukan oleh bagaimana perusahaan mendapatkan tingkat keuntungan yang maksimal dan selalu meningkat pada masa depan.

Kontribusi pada penelitian ini diharapkan pihak manjemen perusahaan lebih memperhatikan faktor fundamental dasar dari rasio keuangan perusahan yang berpengaruh signifikan terhadap ROE. Penelitian yang akan datang dapat menambah atau menggunakan ROA, ROI, EPS, deviden atau menambah faktor eksternal perusahaan. Keterbatasan dalam penelitian hanya meneliti pada periode penelitian relatif singkat yaitu periode 2016 sampai 2018, sehingga berakibat pada kurang mencerminkan kondisi perusahaan dalam jangka panjang. Penelitian yang akan datang disarankan untuk menambah periode waktu penelitian sehingga hasil penelitian dapat digeneralisasikan.

\section{DAFTAR PUSTAKA}

Anggraeni, Desy. (2015). Pengaruh Current Ratio, Quick Ratio, Debt to Equity Ratio dan Ukuran Perusahaan Terhadap Kinerja Perusahaan (Studi Empiris Pada Perusahaan Manufaktur Sub Sektor Makanan dan Minuman yang Terdaftar Di Bursa Efek Indonesia Periode 2012-2014). Jurnal Akuntansi dan Keuangan FE Universitas Budi Luhur Vol. 4 No. 2.

Bastian, Indra, (2006), Akuntansi Sektor Publik: Suatu Pengantar. Erlangga: Jakarta.

Efendi, Azzalia F. W., dan Wibowo, Seto S. A. (2017). Pengaruh Debt to Equity ratio (DER) dan DEBT to Asset Ratio (DAR) terhadap Kinerja Perusahan di Sektor Keuanganyang Terdaftar di Bursa Efek Indonesia. Journal of Applied Managerial Accounting. Vol. 1, No.2 , 2017, 157-163.

Harahap, Sofyan Syafri, (2015), Analisis Kritis atas Laporan Keuangan. Rajawali Pers: Jakarta 
Harjadi, S. (2013). Pasar Modal Indonesia Pengantar dan Analisis. In Media: Jakarta.

Husnan, Suad. (2001). Dasar-Dasar Teori Portofolio dan Analisis Sekuritas. AMP YKPN: Yogyakarta.

Munawir, S., (2010), Analisis Laporan Keuangan. Liberty: Yogyakarta

Nyonita, Ratna Sari, Musriha, dan Enny Istanti., (2017). Pengaruh Leverage, Likuiditas, Profitabilitas Terhadap Kinerja Perusahaan Pada PT. Kimia Farma Tbk. Yang Terdaftar Dibursa Efek Indonesia Tahun 2011-2016. Jurnal Manajemen Branchmark Vol 3 Issue 3.

Oima, David., et al. (2015). Effect of Liquidity on Financial Performance of the Sugar Industry in Kenya. International Journal of Education and Research, Vol. 6 No. 6 June 2018 Kenya: Maseno University Kenya.

Parmono, Heri. (2013). Pengaruh Rasio Keuangan Terhadap Return on Equity pada Perusahaan Farmasi yang Terdaftar di Bursa Efek Indonesia (Studi Kasus pada Perusahaan Farmasi yang Go Public di Bursa Efek Indonesia Periode 20072011). Other Tesis UPN "Veteran" Yogyakarta.

Sundajaja, Ridwan S dan Barlian, Inge. (2003). Manajemen Keuangan. Literata Lintas Media: Jakarta.

Syamsudin, Lukman. (2007). Manajemen Keuangan Perusahaan. PT Raja Grafindo Persada: Jakarta 